\title{
Ammonia Assimilation by Rhizobium Cultures and Bacteroids
}

\author{
By C. M. BROWN* \\ Department of Microbiology, The University, Newcastle-upon-Tyne NE I $7 R U$ \\ AND M. J. DILWORTH \\ Department of Botany, The University, Durham DHI $3 L E$
}

(Received I3 May 1974; revised 26 July 1974)

SUMMAR Y

The enzymes involved in the assimilation of ammonia by free-living cultures of Rhizobium spp. are glutamine synthetase (EC. 6.3 I.2), glutamate synthase (Lglutamine:2-oxoglutarate amino transferase) and glutamate dehydrogenase (EC I.4. I .4). Under conditions of ammonia or nitrate limitation in a chemostat the assimilation of ammonia by cultures of $R$. leguminosarum, $R$. trifolii and $R$. japonicum proceeded via glutamine synthetase and glutamate synthase. Under glucose limitation and with an excess of inorganic nitrogen, ammonia was assimilated via glutamate dehydrogenase, neither glutamine synthetase nor glutamate synthase activities being detected in extracts. The coenzyme specificity of glutamate synthase varied according to species, being linked to NADP for the fast-growing $R$. leguminosarum, $R$. melitoti, $R$. phaseoli and $R$. trifolii but to NAD for the slowgrowing $R$. japonicum and $R$. lupini.

Glutamine synthetase, glutamate synthase and glutamate dehydrogenase activities were assayed in sonicated bacteroid preparations and in the nodule supernatants of Glycine max, Vicia faba, Pisum sativum, Lupinus luteus, Medicago sativa, Phaseolus coccineus and $P$. vulgaris nodules. All bacteroid preparations, except those from $M$. sativa and $P$. coccineus, contained glutamate synthase but substantial activities were found only in Glycine max and Lupinus luteus. The glutamine synthetase activities of bacteroids were low, although high activities were found in all the nodule supernatants. Glutamate dehydrogenase activity was present in all bacteroid samples examined. There was no evidence for the operation of the glutamine synthetase/glutamate synthase system in ammonia assimilation in root nodules, suggesting that ammonia produced by nitrogen fixation in the bacteroid is assimilated by enzymes of the plant system.

\section{INTRODUCTION}

The assimilation of ammonia by bacteria proceeds via either glutamate dehydrogenase or the glutamine synthetase/glutamate synthase system, depending upon the organism and the ammonia concentration of the environment (Tempest, Meers \& Brown, I973; Brown, Macdonald-Brown \& Meers, 1974). Dainty (1972) reported the presence of glutamate synthase in a strain of Clostridium pasteurianum which lacked glutamate dehydrogenase, while Nagatani, Shimizu \& Valentine (197I) demonstrated the presence of glutamate synthase in a range of nitrogen-fixing bacteria and in bacteroids of Rhizobium japonicum prepared from Glycine max (soya bean) root nodules. Nagatani et al. (1971) claimed that the glutamine synthetase/glutamate synthase system was operative in ammonia assimilation

\footnotetext{
* Present address: Department of Biological Sciences, University of Dundee, Dundee DDI $4 \mathrm{HN}$.
} 
during nitrogen fixation but these results have been criticized by Drozd, Tubb \& Postgate (1972) on the grounds that the ill-defined cultural conditions used would invalidate the conclusions reached. Drozd et al. (1972) used chemostat cultures to study the assimilation of ammonia in Azotobacter chroococcum. In this organism, extracts from cultures grown on molecular nitrogen, nitrate or ammonia all contained both glutamate dehydrogenase and glutamate synthase. These authors did not report on the activities of glutamine synthetase. Fottrell \& Mooney (1969) studied ammonia assimilation in $R$. japonicum and found that glutamate dehydrogenase was present in extracts of cultures grown on aspartate or glutamate, and that glutamine synthetase activity was low in rhizobia grown on ammonia or nitrate but was a roo-fold greater when grown on glutamate.

Ammonia is the primary product of symbiotic nitrogen fixation. Bergersen (1965), using detached soybean nodules, showed that after I min incubation with ${ }^{15} \mathrm{~N}_{2}$ more than $90 \%$ of the soluble fixed nitrogen could be accounted for as ammonia. From pulse labelling experiments with ${ }^{15} \mathrm{~N}_{2}$ and serradella (Ornithopus sativus) nodules, Kennedy (r966) concluded that ammonia was the primary fixation product with glutamate and glutamine as the primary amino acids. Grimes \& Fottrell (1966) demonstrated glutamate dehydrogenase in Trifolium repens nodules and found activities linked to either NAD or NADP after the electrophoresis of homogenized nodule extracts on starch gels. Only $10 \%$ of total NAD-linked activity was present in the bacteroids while some $73 \%$ was detected in the nodule supernatant (plant) fraction. These nodules, however, were frozen before being homogenized. Grimes \& Turner (I97I) showed that nodules from Pisum sativum contained a higher NAD-linked glutamate dehydrogenase activity than did the plant root or shoot.

Kennedy (1973) found glutamine synthetase and glutamate synthase in bacteroids derived from lupin nodules. The glutamate synthase from lupin bacteroids had a very low Michaelis constant for 2-oxoglutarate, was NAD-specific and was strongly inhibited by low concentrations of aspartic acid. Subsequently, Dunn \& Klucus (1973) reported particularly high levels of glutamine synthetase in both plant and bacteroid fractions of soybean nodules. The glutamate synthase activity of the bacteroids was compatible with the rate of $\mathrm{N}_{2}$ fixation. The glutamine synthetase activities in the plant fraction were the major part of the total nodule activity.

This paper describes attempts to establish the mode of ammonia assimilation both in laboratory cultures of Rhizobium spp. grown on different nitrogen sources and in the nitrogen-fixing root nodules of several legumes, and to relate it to the rate of nitrogen fixation of intact nodules (measured as acetylene reduction).

\section{METHODS}

The Rhizobium cultures, Rhizobium leguminosarum (wU47), R. japonicum (WIS505), $R$. trifolii (WUI) and $R$. meliloti (WU60) were maintained on a potato extract-yeast-mannitol medium (Broughton \& Dilworth, 1971).

The medium used for batch and continuous cultures had the following composition (per litre distilled water): $2.5 \mathrm{~g}$ glucose, $0.36 \mathrm{~g} \mathrm{KH}_{2} \mathrm{PO}_{4}$, I. $4 \mathrm{~g} \mathrm{~K}_{2} \mathrm{HPO}_{4}, 0.25 \mathrm{~g} \mathrm{MgSO}_{4} \cdot 7 \mathrm{H}_{2} \mathrm{O}$, $0.02 \mathrm{~g} \mathrm{CaCl}_{2} .2 \mathrm{H}_{2} \mathrm{O}, 0.2 \mathrm{~g} \mathrm{NaCl}, 6.6 \mathrm{mg} \mathrm{FeCl}_{3}$, I $5 \mathrm{mg}$ EDTA, 0.1 $6 \mathrm{mg} \mathrm{ZnSO} \mathrm{Zn}_{4} .7 \mathrm{H}_{2} \mathrm{O}, 0.2 \mathrm{mg}$, $\mathrm{Na}_{2} \mathrm{MoO}_{4}, 0.25 \mathrm{mg} \mathrm{H}_{3} \mathrm{BO}_{3}, 0.2 \mathrm{mg} \mathrm{MnSO}{ }_{4} .4 \mathrm{H}_{2} \mathrm{O}, 0.02 \mathrm{mg} \mathrm{CuSO}{ }_{4} \cdot 5 \mathrm{H}_{2} \mathrm{O}, \mathrm{x} \mu \mathrm{g} \mathrm{CoCl}_{2} .6 \mathrm{H}_{2} \mathrm{O}$, $\mathrm{I} \mathrm{mg}$ thiamine- $\mathrm{HCl}, 2 \mathrm{mg}$ calcium pantothenate and $\mathrm{I} \mu \mathrm{g}$ biotin. The nature and concentrations of the nitrogen sources were varied as required.

Continuous cultures were grown at $30{ }^{\circ} \mathrm{C}$ in $\mathrm{I} \cdot 0$ or $2 \cdot 01$ capacity chemostats (Brown \& Rose, ${ }^{1969)}$ at $\mathrm{pH} 7 \cdot 0$ and the dilution rate varied according to the organism. Batch cultures 
were harvested in the late logarithmic phase of growth and continuous cultures direct from the culture vessel. The preparation and assay of extracts were carried out as described by Brown, Macdonald-Brown \& Stanley (1972).

Seeds of broad bean (Vicia faba L.), pea (Pisum sativum L.), lucerne (Medicago sativa L.) and yellow lupin (Lupinus luteus $\mathrm{L}$.) were inoculated with cultures of $R$. leguminosarum (wU47), R. meliloti (WU60) and R. lupini (wU8) suspended in sterile $2 \%(\mathrm{w} / \mathrm{v}$ ) sucrose solution and sown in the field at Durham. Red runner beans (Phaseolus coccineus L.) were sown without inoculation in Durham. Phaseolus vulgaris plants and nodules were kindly provided by the Vegetable Research Station of the Western Australia Department of Agriculture and processed in Australia. Glycine max Merr. plants, kindly provided by Dr P. J. Dart of the Rothamsted Experimental Station, were grown in glass houses at Rothamsted after inoculation with $R$. japonicum (WIS505); these plants were processed in Newcastle on the day they were harvested.

For the preparation of bacteroids, Io to $30 \mathrm{~g}$ of nodules from freshly harvested plants (with the exception of soybean) were washed in tap water and suspended in $150 \mathrm{ml} \mathrm{O.I} \mathrm{M-}$ potassium phosphate buffer $\mathrm{pH} 7.6$ containing $0.2 \mathrm{M}$-sucrose, $0.5 \mathrm{mM}$-dithiothreitol and $2 \%(\mathrm{w} / \mathrm{v})$ soluble polyvinylpyrrolidone. The nodule suspensions were homogenized for I min on an Atomix homogenizer (Measuring \& Scientific Equipment Ltd, London) after the head space had been flushed with $\mathrm{N}_{2}$. The homogenized suspension was filtered with gentle suction through a glass sintered funnel (porosity $\mathrm{I}$ ), the filtrate collected and centrifuged at $4500 \mathrm{~g}$ for $\mathrm{I} 5 \mathrm{~min}$. The supernatant (i.e. plant) fraction was stored in ice until required. The precipitate containing the bacteroids was resuspended in 0.1 M-potassium phosphate buffer $\mathrm{pH} 7.6$ and washed once in the same buffer before extracts were prepared by sonication as for culture suspensions. All extracts were assayed as soon as possible.

Acetylene reduction rates were estimated on the nodulated root systems of plants from the same batch as those used for the preparation of bacteroids. Acetylene was injected into the I 1 glass bottle closed with a serum stopper, after equilibration of temperature to $28{ }^{\circ} \mathrm{C}$. The acetylene concentration was $5 \%(\mathrm{v} / \mathrm{v})$. Gas samples ( $\mathrm{I} \mathrm{ml}$ ) were subsequently analysed on a Pye Series 104 gas chromatograph (Pye/Unicam, Cambridge) with a flame ionization detector, using a column of Porapak $\mathrm{R}\left(\mathrm{I} .6 \mathrm{~m} \times 4 \mathrm{~mm}\right.$ diam) at $50^{\circ} \mathrm{C}$ and a carrier gas flow $\left(\mathrm{N}_{2}\right)$ of $30 \mathrm{ml} / \mathrm{min}$. Peak heights for ethylene and acetylene were used to calculate ethylene production from the time course.

The protein content of extracts was estimated by the method of Lowry, Rosebrough, Farr \& Randall (I95I) with bovine serum albumin as standard.

\section{RESULTS}

\section{Laboratory cultures}

Preliminary experiments with batch cultures established that $R$. leguminosarum synthesized glutamine synthetase (GS), NADP-linked glutamate synthase (GOGAT) and both NAD- and NADP-linked glutamate dehydrogenase (GDH). Glutamine synthetase had a low $K_{m}$ for hydroxylamine (used in the biosynthetic assay as an analogue of ammonia) and glutamate synthase a low $K_{m}$ for 2-oxoglutarate (Table I). Dunn \& Klucas (I973) reported considerably lower $K_{m}$ values for both glutamine and 2-oxoglutarate for the glutamate synthase from $R$. japonicum bacteroids but a considerably higher $K_{m}$ for ammonia for glutamate dehydrogenase. Sloger (1973) reported that the Michaelis-Menten plot for glutamine synthetase (apparently from $R$. japonicum) was biphasic with $K_{m}$ values for 
Table I. Some kinetic constants of the ammonia assimilating enzymes of $R$. leguminosarum

\begin{tabular}{llc}
\multicolumn{1}{c}{ Enzyme } & \multicolumn{1}{c}{ Substrate } & $K_{m}(\mathrm{~mm})$ \\
Glutamate dehydrogenase & 2-Oxoglutarate & $0 \cdot 8$ \\
Glutamate dehydrogenase & Ammonia & $\mathbf{1} 3 \cdot 9$ \\
Glutamate synthase & 2-Oxoglutarate & $0 \cdot 3$ \\
Glutamate synthase & Glutamine & $4 \cdot 4$ \\
Glutamine synthetase & Hydroxylamine & $0 \cdot 4$ \\
Glutamine synthetase & Glutamate & $5 \cdot 3$
\end{tabular}

ammonia of 0.I6 and I mM. Kennedy (I973) noted that the $K_{m}$ for 2-oxoglutarate for $R$. lupini bacteroid glutamate synthase was extremely low (less than I $\mu \mathrm{M}$ ).

The $\mathrm{pH}$ optimum for glutamate synthase was in the region of $7 \cdot 6$, and therefore similar to the enzymes from Aerobacter aerogenes, Escherichia coli and Pseudomonas spp. (Tempest, Meers \& Brown, 1970; Miller, 1973; Brown, Macdonald-Brown \& Stanley, 1973). The activity of $R$. leguminosarum glutamate synthase was dependent on the buffer used in the assay system, highest activities being obtained with phosphate or $N$-2-hydroxyethylpiperizine- $N^{\prime}$-2-ethanesulphonic acid (HEPES) buffer (100\%), while imidazole $(57 \%)$ and tris ( $10 \%$ ) gave greatly reduced activities. All further glutamate dehydrogenase and glutamate synthase assays were done at $30^{\circ} \mathrm{C}$ in $67 \mathrm{mM}$-phosphate buffer at $\mathrm{pH} 7 \cdot 6$.

To establish the response of glutamine synthetase, glutamate synthase and glutamate dehydrogenase activities to different sources and concentrations of nitrogen, chemostat cultures of three Rhizobium species were established. The relatively fast-growing $R$. leguminosarum (Table 2) was grown at a dilution rate of $0.15 \mathrm{~h}^{-1}$ with ammonia, glutamate or nitrate in limiting or excess concentrations as nitrogen source. Concentrations of 25 and $50 \mu \mathrm{g} \mathrm{N} / \mathrm{ml}$ produced nitrogen-limited cultures with little residual nitrogen in the culture filtrates, while $200 \mu \mathrm{g} \mathrm{N} / \mathrm{ml}$ produced a glucose-limited system with an excess of nitrogen in the culture filtrates. In limiting nitrogen, the activities of glutamine synthetase, glutamate synthase and NADP-linked glutamate dehydrogenase were high. With an excess of ammonia or nitrate, however, neither glutamine synthetase nor glutamate synthase were detected but the NADP-linked glutamate dehydrogenase level remained high." An excess of glutamate did not lower glutamine synthetase activity in extracts but glutamate synthase activity was reduced by some $75 \%$. The reduced activity of NADP-linked glutamate dehydrogenase in cultures grown at $200 \mu \mathrm{g}$ nitrate- $\mathrm{N} / \mathrm{ml}$ may be connected with an accumulation of nitrite under these conditions. NAD-linked glutamate dehydrogenase activity was detected in most extracts but the levels recorded were lower than those of the NADP-linked enzyme.

Chemostat cultures of $R$. trifolii were maintained at a dilution rate of $0 \cdot 12 \mathrm{~h}^{-1}$ (Table 3 ) with limiting or excess concentrations of ammonia or glutamate. An excess of ammonia or glutamate produced lower glutamine synthetase and glutamate synthase activities than those from cultures grown under ammonia or glutamate limitations. The activities of the NADP-linked glutamate dehydrogenase were low in glutamate-grown and ammonialimited cultures but increased markedly in the presence of an ammonia excess. NAD-linked glutamate dehydrogenase activity was present in all cultures studied.

The slow-growing $R$. japonicum was grown at a dilution rate of $0.05 \mathrm{~h}^{-1}$ on limiting or excess concentrations of ammonia or glutamate (Table 4). Glutamate synthase activities were present in all cultures tested but while glutamine synthetase activity was high in glutamate-grown and ammonia-limited cultures no activity was recorded in the presence of 
Table 2. Influence of nitrogen source and concentration on the activities of ammonia assimilatory enzymes in $R$. leguminosarum

\begin{tabular}{|c|c|c|c|c|c|c|}
\hline \multicolumn{2}{|c|}{ Nitrogen } & \multirow[b]{2}{*}{$\begin{array}{l}\text { Limiting } \\
\text { substrate }\end{array}$} & \multicolumn{4}{|c|}{ Enzyme activity (nmol/min $/ \mathrm{mg}$ protein) } \\
\hline Source & $\begin{array}{c}\text { Concentration } \\
(\mu \mathrm{g} / \mathrm{ml})\end{array}$ & & GS & GOGAT & $\begin{array}{c}\text { GDH } \\
\text { (NAD) }\end{array}$ & $\begin{array}{c}\text { GDH } \\
\text { (NADP) }\end{array}$ \\
\hline Ammonia & $\begin{array}{r}25 \\
50 \\
200\end{array}$ & $\begin{array}{l}\text { Ammonia } \\
\text { Ammonia } \\
\text { Glucose }\end{array}$ & $\begin{array}{l}48 \cdot 8 \\
58 \cdot 6 \\
\text { ND }\end{array}$ & $\begin{array}{l}24 \cdot 7 \\
27 \cdot 9 \\
\text { ND }\end{array}$ & $\begin{array}{r}8 \cdot 2 \\
11 \cdot 6 \\
12 \cdot 4\end{array}$ & $\begin{array}{l}43 \cdot 6 \\
49 \cdot 8 \\
45 \cdot 4\end{array}$ \\
\hline Glutamate & $\begin{array}{r}25 \\
50 \\
200\end{array}$ & $\begin{array}{l}\text { Glutamate } \\
\text { Glutamate } \\
\text { Glucose }\end{array}$ & $\begin{array}{l}56 \cdot I \\
47 \cdot 6 \\
43 \cdot I\end{array}$ & $\begin{array}{r}2 I \cdot 4 \\
19 \cdot I \\
5 \cdot 6\end{array}$ & $\begin{array}{r}5 \cdot 2 \\
11 \cdot 6 \\
14 \cdot 6\end{array}$ & $\begin{array}{l}25 \cdot 8 \\
25 \cdot 4 \\
24 \cdot 7\end{array}$ \\
\hline Nitrate & $\begin{array}{r}25 \\
50 \\
200\end{array}$ & $\begin{array}{l}\text { Nitrate } \\
\text { Nitrate } \\
\text { Glucose }\end{array}$ & $\begin{array}{l}65 \cdot 7 \\
63 \cdot 5 \\
\text { ND }\end{array}$ & $\begin{array}{l}31 \cdot 0 \\
28 \cdot 6 \\
\text { ND }\end{array}$ & $\begin{array}{l}\text { ND } \\
\text { II } 0 \\
15 \cdot 8\end{array}$ & $\begin{array}{l}48 \cdot 7 \\
39 \cdot 6 \\
34 \cdot 0\end{array}$ \\
\hline
\end{tabular}

Table 3. Influence of nitrogen source and concentration on the activities of ammonia assimilatory enzymes in $R$. trifolii

\begin{tabular}{|c|c|c|c|c|c|c|}
\hline \multicolumn{2}{|c|}{ Nitrogen } & \multirow[b]{2}{*}{$\begin{array}{l}\text { Limiting } \\
\text { substrate }\end{array}$} & \multicolumn{4}{|c|}{ Enzyme activity (nmol $/ \mathrm{min} / \mathrm{mg}$ protein) } \\
\hline Source & $\begin{array}{l}\text { Concentration } \\
(\mu \mathrm{g} / \mathrm{ml})\end{array}$ & & GS & GOGAT & $\begin{array}{c}\text { GDH } \\
\text { (NAD) }\end{array}$ & $\begin{array}{c}\text { GDH } \\
\text { (NADP) }\end{array}$ \\
\hline Ammonia & $\begin{array}{r}50 \\
200\end{array}$ & $\begin{array}{l}\text { Ammonia } \\
\text { Glucose }\end{array}$ & $\begin{array}{l}34 \cdot 9 \\
\text { ND }\end{array}$ & $\begin{array}{r}13.4 \\
7.9\end{array}$ & $\begin{array}{l}6 \cdot 9 \\
9 \cdot 8\end{array}$ & $\begin{array}{r}3 \cdot 9 \\
25 \cdot 4\end{array}$ \\
\hline Glutamate & $\begin{array}{r}20 \\
200\end{array}$ & $\begin{array}{l}\text { Glutamate } \\
\text { Glucose }\end{array}$ & $\begin{array}{l}35.0 \\
11 \cdot 9\end{array}$ & $\begin{array}{l}1 \cdot 5 \\
1 \cdot 2\end{array}$ & $\begin{array}{l}4 \cdot I \\
I \cdot 9\end{array}$ & $\begin{array}{l}1 \cdot 3 \\
3 \cdot 6\end{array}$ \\
\hline
\end{tabular}

Table 4. Influence of nitrogen source and concentration on the activities of ammonia assimilatory enzymes in $R$. japonicum

$\begin{array}{lc}\text { Source } & \begin{array}{c}\text { Concentration } \\ (\mu \mathrm{g} / \mathrm{ml})\end{array} \\ \text { Ammonia } & 50 \\ \text { Glutamate } & 200 \\ & 50 \\ 200\end{array}$

Limiting
substrate
Ammonia
Glucose
Ammonia
Glucose

\begin{tabular}{lccc}
\multicolumn{4}{c}{ Enzyme activity (nmol/min/mg protein) } \\
GS & GOGAT & $\begin{array}{c}\text { GDH } \\
\text { (NAD) }\end{array}$ & $\begin{array}{c}\text { GDH } \\
\text { (NADP) }\end{array}$ \\
40.8 & 37.8 & ND & ND \\
ND & 28.6 & ND & 107.0 \\
44.2 & 53.8 & ND & ND \\
46.1 & 46.1 & ND & 7.9
\end{tabular}

ND, Not detected.

an ammonia excess. No NAD-linked glutamate dehydrogenase was detected in extracts of this organism grown in chemostat culture although bacteroids contain appreciable levels (Table 5; see also Dunn \& Klucas, 1973; Sloger, I973).

The activities of chemostat cultures indicate different patterns of control in the three Rhizobium species. As with other bacterial systems (Meers, Tempest \& Brown, I970; Meers \& Pedersen, 1972; Brown et al. 1972), however, extracts from these organisms grown under nitrogen limitation contained both glutamine synthetase and glutamate synthase in amounts sufficient to account for ammonia assimilation, and it is assumed that this is the assimilatory route under these conditions. The coenzyme specificity of glutamate synthase 
Table 5. Activity of ammonia assimilatory enzymes in bacteroid extracts

\begin{tabular}{|c|c|c|c|c|c|c|}
\hline \multirow[b]{2}{*}{ Organism } & \multirow[b]{2}{*}{ Nodule source } & \multicolumn{5}{|c|}{ Enzyme activity (nmol/min/mg protein) } \\
\hline & & GS & $\begin{array}{l}\text { GOGAT } \\
\text { (NAD) }\end{array}$ & $\begin{array}{l}\text { GOGAT } \\
\text { (NADP) }\end{array}$ & $\begin{array}{c}\text { GDH } \\
\text { (NAD) }\end{array}$ & $\begin{array}{c}\text { GDH } \\
\text { (NADP) }\end{array}$ \\
\hline R. japonicum & Glycine $\max$ & $6 \cdot 4$ & $55 \cdot 8$ & ND & $19 \cdot 6$ & $4 \cdot 2$ \\
\hline R. leguminosarum & Vicia faba & $4 \cdot 2$ & ND & $12 \cdot 3$ & 15.5 & ND \\
\hline R. leguminosarum & Pisum sativum & 0.4 & ND & $I \cdot 4$ & $33 \cdot 4$ & ND \\
\hline R. lupini & Lupinus luteus & $3 \cdot I$ & $34 \cdot 5$ & ND & 10.8 & ND \\
\hline R. meliloti & Medicago sativa & 4.0 & ND & ND & $8 \cdot 3$ & $16 \cdot 7$ \\
\hline R. phaseoli & Phaseolus coccineus & $4 \cdot 8$ & ND & ND & ND & $34 \cdot 6$ \\
\hline R. phaseoli & P. vulgaris & 2.6 & ND & $1 \cdot 2$ & $\mathrm{I} \cdot 6$ & ND \\
\hline
\end{tabular}

varied from species to species, NADP-linked enzymes occurring in the fast-growing types ( $R$. leguminosarum, $R$. meliloti, $R$. phaseoli, $R$. trifolii) and NAD-linked enzymes in the slowgrowing types ( $R$. japonicum, $R$. lupini). This specificity extends even to situations where the one legume is nodulated effectively by both fast- and slow-growing types. Thus NGR234 (fast-growing) and NGR46 (slow-growing) (Broughton \& Dilworth, I97I) both nodulated snake bean (Vigna sesquipedalis), but the former has an NADP-linked and the latter an NAD-linked glutamate synthase.

Rhizobium leguminosarum differed from $R$. japonicum and $R$. trifolii in containing NADPlinked glutamate dehydrogenase irrespective of the culture conditions in the chemostat, and appeared to be constitutive. Since bacteroids did not contain this activity (Table 5) attempts were made to approach the bacteroid environment by decreasing both the growth rate and the oxygen tension. These changes did not, however, influence enzyme activity. The high $K_{m}$ for ammonia ( $44 \mathrm{~mm}$ ) suggests that this enzyme only makes a significant contribution to ammonia assimilation under conditions of nitrogen excess. When grown on ammonia excess all three organisms assimilate ammonia via glutamate dehydrogenase; $R$. japonicum and $R$. trifolii cultures grown in this way contained the most NADP-linked glutamate dehydrogenase activities and lacked glutamine synthetase and/or glutamate synthase. Cultures of $R$. leguminosarum grown with excess nitrate did not contain detectable glutamine synthetase or glutamate synthase activities. In this respect $R$. leguminosarum differed from Pseudomonas spp. and A. aerogenes (Brown et al. 1973; Brown \& Dilworth, 1974) where ammonia assimilation in the presence of an excess of nitrate proceeded via glutamine synthetase and glutamate synthase with little or no biosynthetic glutamate dehydrogenase activity. Apparently in Pseudomonas spp. and in A. aerogenes nitrate uptake and reduction to ammonia is a limiting step, but not in $R$. leguminosarum.

When cultures of $R$. meliloti were grown in low concentrations of ammonia $(50 \mu \mathrm{g} \mathrm{N} / \mathrm{ml})$, extracts contained glutamine synthetase, glutamate synthase linked to NADP, and glutamate dehydrogenase activity linked to both NAD and NADP. Batch cultures of an isolate from Phaseolus vulgaris nodules grown in a yeast-potato extract medium lacking inorganic nitrogen indicated that $R$. phaseoli produced high glutamine synthetase and NADP-linked glutamate dehydrogenase activities and low NADP-linked glutamate synthase.

\section{Bacteroids and plant extracts prepared from root nodules}

Bacteroids were prepared from root nodules of soybeans, broad beans, peas, lupins, lucerne, red runner and runner beans, and assays of glutamine synthetase, glutamate 


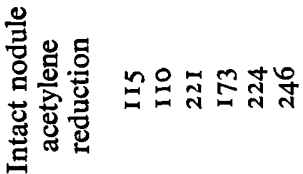

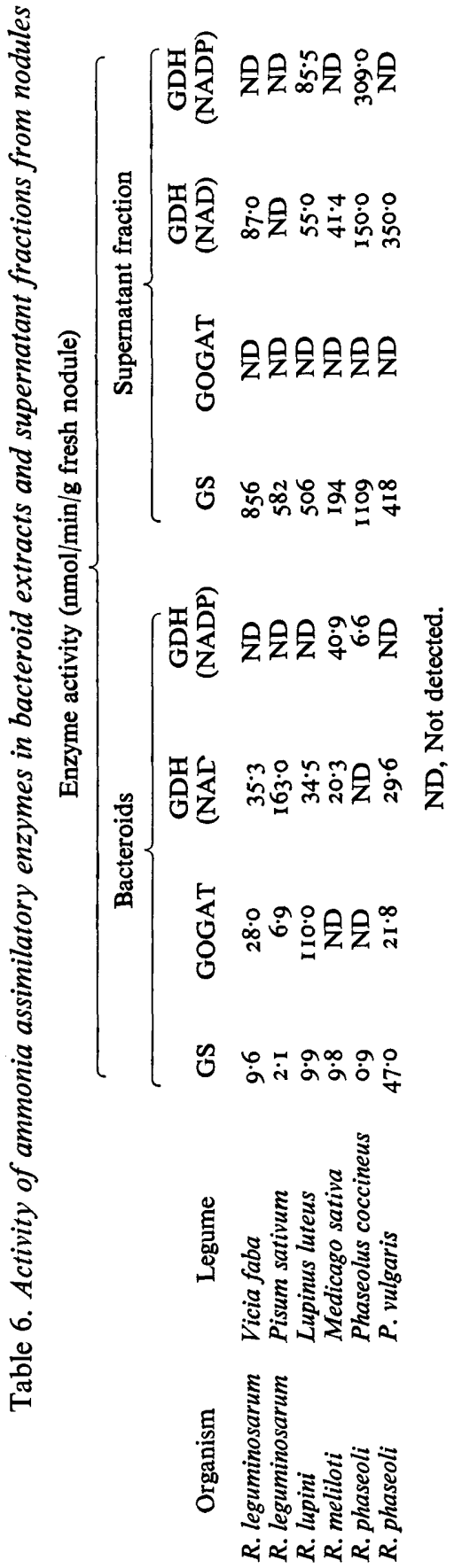


synthase and glutamate dehydrogenase were carried out on sonicated preparations. With the exception of soybeans, acetylene reduction rates were estimated on the plant root systems at the same time. The GS activities of all the bacteroids were low and, in $R$. leguminosarum, much lower in bacteroids from pea nodules than in those obtained from broad beans (Table 5). Since Dunn \& Klucas (1973) report extremely high glutamine synthetase activities in $R$. japonicum bacteroids, it is possible that the time in transit of the soybeans from Rothamsted to Newcastle was sufficient to inactivate the glutamine synthetase in the nodules, though it had little effect on the glutamate synthase. Dunn \& Klucas, however, assayed glutamine synthetase as the transferase activity of that enzyme (see Shapiro \& Stadtman, 1970). We used the biosynthetic assay, since the relationship between these two activities of glutamine synthetase in Rhizobium is unknown.

Five out of seven bacteroid systems contained glutamate synthase. Only $R$. japonicum and $R$. lupini bacteroids had substantial NAD-linked glutamate synthase activities, in agreement with the results of Dunn \& Klucas (1973) and Kennedy (1973), respectively. As expected from laboratory-grown cultures, $R$. leguminosarum bacteroids contained NADPlinked glutamate synthase. No glutamate synthase activity was recorded in $R$. meliloti or in $R$. phaseoli bacteroids from red runner bean, though low but definite activity occurred in preparations from Phaseolus vulgaris.

All the bacteroid preparations contained glutamine dehydrogenase; all but $R$. phaseoli contained NAD-linked activity.

In Table 6 these results, together with the activities of the plant extracts, are expressed on the basis of nodule fresh weight together with the acetylene reduction rates of the intact nodules. In no case did the activities of the ammonia assimilatory enzymes of the bacteroids match those of the nodule nitrogen fixation rates. While no plant extract contained detectable glutamate synthase, all contained substantial glutamine synthetase activities well in excess of rates of $\mathrm{NH}_{3}$ formation from $\mathrm{N}_{2}$. Extracts from all the nodules contained NAD-linked glutamate dehydrogenase in the plant fraction, while soybeans contained smaller and lupins and red runner beans higher NADP-linked glutamate dehydrogenase activities.

\section{DISCUSSION}

These results from chemostat cultures of $R$. japonicum agree with those of Fottrell \& Mooney (I969). The nitrogen concentrations employed by these authors ( $7 \mathrm{~mm}-\mathrm{KNO}_{3}$ or I 4 mM- $\mathrm{NH}_{4} \mathrm{Cl}$ ) were sufficiently high to have resulted in a loss of glutamine synthetase activity, while our experiments indicate that glutamine synthetase activity would not have been decreased by growth on glutamate. Our results also substantiate their report that glutamate dehydrogenase was repressed during growth on glutamate.

The results obtained with bacteroids do not correspond to the pattern of enzyme activities shown in the free-living bacteria. The low glutamine synthetase activities of these extracts suggest that bacteroids are not nitrogen limited. These low values could be due to the preparative procedure employed, but this seems unlikely since very high activities were found in the nodule supernatant fraction. It is unlikely that this is due to leakage from the bacteroids because glutamate synthase, when present in nodules, was found consistently in the bacteroids and not in the supernatant fraction. The marker enzyme 3-hydroxybutyrate dehydrogenase was also found exclusively in the bacteroid fraction. The glutamine synthetase activity of the bacteroid preparations was insufficient to account for the level of nitrogen fixation and assimilation indicated by the acetylene reduction rates of the intact nodule, while that of the nodule supernatant fraction was more than sufficient to account 
for the overall rate of ammonia assimilation from $\mathrm{N}_{2}$. Possibly the small glutamine synthetase activities detected in bacteroids of $R$. japonicum by Dunn \& Klucas (1973) and in our bacteroids result from enzyme adsorption from the extremely active plant fraction. Adsorption occurred with the invertase associated with bacteroids of $R$. lupini prepared from nodules of Lupinus luteus (Kidby, I966).

We have no evidence for the operation of the glutamine synthetase/glutamate synthase system in symbiotic ammonia assimilation in root nodules. It is more likely that ammonia produced in the nodule by nitrogen fixation is then assimilated by enzymes from the plant. If the primary product of assimilation was glutamate, glutamine and asparagine could readily be produced from it. If the primary compound formed was glutamine, synthesis of glutamate by reductive amination of 2-oxoglutarate in the nodule would be necessary unless glutamate was returned to the nodule from the plant top via the phloem in sufficient quantity to act as the ammonia acceptor. With isolated soybean bacteroids exposed to ${ }^{15} \mathrm{~N}_{2}$ nearly all the ${ }^{15} \mathrm{~N}$ is found outside the bacteroid as ${ }^{15} \mathrm{NH}_{3}$ (Bergersen \& Turner, ${ }^{1967}$ ).

The function of the ammonia-assimilatory enzymes of the bacteroids may be to maintain an adequate supply of amino acids for bacteroid proteins, or they may be synthesized because they are constitutive. In $R$. japonicum bacteroids the glutamate synthase level is high and it varied only slightly with nitrogen source and concentration in chemostat cultures. It is not apparent whether the measured glutamate synthase or glutamate dehydrogenase activities function in the bacteroid in the nodule; $E$. coli glutamate synthase, for example, is inhibited by a range of amino acids (Miller, 1973), and nodule amino acid concentrations range from I $3 \mathrm{~mm}$ for Glycine max to $67 \mathrm{~mm}$ for Pisum sativum (J. S. Pate, unpublished). Further, glutamate synthase from $R$. lupini bacteroids is $50 \%$ inhibited by $0.5 \mathrm{~mm}$-aspartate (Kennedy, 1973) while aspartate concentrations in Lupinus albus nodules are about $2 \cdot 3 \mathrm{~mm}$ in the nodule (J. S. Pate, unpublished).

This work was supported by a grant from the Science Research Council.

\section{REFERENCES}

Bergersen, F. J. (1965). Ammonia - an early stable product of nitrogen fixation by soybean root nodules. Australian Journal of Biological Sciences 18, I-9.

Bergersen, F. J. \& TuRner, G. L. (I967). Nitrogen fixation by the bacteroid fraction of breis of soybean root nodules. Biochimica et biophysica acta 141, 507-51 5 .

Broughton, W. J. \& Dilworth, M. J. (I97I). Control of leghaemoglobin synthesis in snake beans. Biochemical Journal I25, 1075-1080.

Brown, C. M. \& Dilworth, M. J. (1974). Ammonia assimilation during the growth of some microorganisms on nitrate. Proceedings of the Society for General Microbiology I, 2.

Brown, C. M., Macdonald-Brown, D. S. \& Meers, J. L. (1974). Physiological aspects of microbial inorganic nitrogen metabolism. Advances in Microbial Physiology II, I-52.

Brown, C. M., Macdonald-Brown, D. S. \& Stanley, S. D. (1972). Inorganic nitrogen metabolism in marine bacteria: nitrogen assimilation in some marine pseudomonads. Journal of the Marine Biological Association of the United Kingdom 52, 793-804.

Brown, C. M., Macdonald-Brown, D. S. \& Stanley, S. O. (1973). The mechanism of nitrogen assimilation in pseudomonads. Antonie van Leeuwenhoek 39, 89-98.

Brown, C. M. \& Rose, A. H. (1969). Effects of temperature on composition and cell volume of Candida utilis. Journal of Bacteriology 97, 261-272.

DAINTY, R. H. (1972). Glutamate biosynthesis in Clostridium pasteurianum and its significance in nitrogen metabolism. Biochemical Journal 126, 1055-1056.

Drozd, J. W., Tubb, R. S. \& Posgate, J. R. (1972). A chemostat study of the effect of fixed nitrogen sources on nitrogen fixation, membranes and free amino acids in Azotobacter chroococcum. Journal of General Microbiology 73, 22 I-232. 
DunN, S. D. \& KuUCAS, R. V. (1973). Studies on possible routes of ammonium assimilation in soybean root nodule bacteroids. Canadian Journal of Microbiology 19, 1493-1499.

Fottrell, P. F. \& MoONEy, P. (1969). The regulation of some enzymes involved in ammonia assimilation by Rhizobium japonicum. Journal of General Microbiology 59, 2 I I-2I4.

Grimes, H. \& FotTrell, P. F. (I966). Enzymes involved in glutamate metabolism in legume root nodules. Nature, London 212, 295-296.

Grimes, H. \& TURNER, S. (I97I). Qualitative and quantitative studies of some enzymes in the nodule, root and shoot of Pisum sativum. Plant and Soil 35, 269-273.

KenNedy, I. R. (1966). Primary products of symbiotic nitrogen fixation. II. Pulse labelling of serradella nodules with ${ }^{15} \mathrm{~N}_{2}$. Biochimica et biophysica acta 130, 295-308.

KENNEDY, I. R. (1973). Glutamine synthetase/glutamate synthetase for ammonia assimilation in symbiotic nitrogen fixation. Proceedings of the Australian Biochemical Society 6, 33.

KIDBY, D. K. (1966). Activation of a plant invertase by inorganic phosphate. Plant Physiology 4I, I I 39-I I 44.

Lowry, O. H., Rosebrough, N. J., Farr, A. L. \& Randall, R. J. (I95I). Protein measurement with the Folin phenol reagent. Journal of Biological Chemistry 193, 265-275.

MeERs, J. L. \& Pedersen, L. K. (1972). Nitrogen assimilation in Bacillus licheniformis organisms growing in chemostat cultures. Journal of General Microbiology 7o, 277-286.

Meers, J. L., Tempest, D. W. \& Brown, C. M. (1970). 'Glutamine (amide): 2-oxoglutarate amino transferase oxidoreductase (NADP)' an enzyme involved in the synthesis of glutamate by some bacteria. Journal of General Microbiology 64, 187-194.

Miller, R. E. (1973). Glutamate synthase from Escherichia coli: an iron-sulphide flavoprotein. In The Enzymes of Glutamine Metabolism, pp. 293-318. Edited by S. Prusiner and E. R. Stadtman. New York: Academic Press.

Nagatani, H., Shimizu, M. \& Valentine, R. C. (197I). The mechanism of ammonia assimilation in nitrogen fixing bacteria. Archiv für Mikrobiologie 79, 164-175.

Shapiro, B. M. \& Stadtman, E. R. (1970). The regulation of glutamine synthesis in micro-organisms. Annual Review of Microbiology 24, 501-524.

SLOGER, C. (1973). Assimilation of ammonia by glutamine synthetase and glutamate synthetase in $\mathrm{N}_{\mathbf{2}}$-fixing bacteroids from soybean nodules. Plant Physiology 51, $\mathrm{s} 34$.

Tempest, D. W., Meers, J. L. \& Brown, C. M. (1970). Synthesis of glutamate in Aerobacter aerogenes by a hitherto unknown route. Biochemical Journal II7, 405-407.

Tempest, D. W., Meers, J. L. \& Brown, C. M. (1973). Glutamate synthetase (GOGAT): a key enzyme in the assimilation of ammonia by prokaryotic organisms. In The Enzymes of Glutamine Metabolism, pp. I67-182. Edited by S. Prusiner and E. R. Stadtman. New York: Academic Press. 